\title{
Transport and Excretion of L-Lysine in Corynebacterium glutamicum
}

\author{
By MARIA G. LUNTZ, NELLY I. ZHDANOVA AND GENRICH I. BOURD* \\ Institute of Genetics and Selection of Industrial Microorganisms, Dorozhnaya 8, \\ Moscow 113545, USSR
}

(Received 30 December 1985; revised 25 March 1986)

\begin{abstract}
L-Lysine transport in Corynebacterium glutamicum was investigated. The bacterium was shown to possess a highly specific, energy-dependent system of active lysine transport. The system transferred lysine into the cells and exchanged intra- and extracellular lysine. Mutations in the transport system did not lead to overproduction of the amino acid. Resting cells of the parent strain, or of its lysine-producer derivatives with a defective transport system, failed to excrete lysine into the medium. An efflux of intracellular lysine could be induced by a hyperosmotic shock, and by different membrane-active substances. It has been suggested that $C$. glutamicum cells are equipped with channels (pores) for excreting lysine from the cytoplasm. These channels appeared to open in response to an increase in the intracellular lysine concentration. The channel permeability also depends on the membrane structure.
\end{abstract}

\section{INTRODUCTION}

Various bacteria used as industrial producers of a number of low molecular mass compounds, including amino acids, excrete these compounds into the cultivation medium. Obviously, the transfer of a water-soluble substance across the bacterial cytoplasmic membrane into the environment requires a special mechanism. Yet our knowledge on the appropriate mechanisms is rather limited.

Three excretion mechanisms are possible. One is associated with a change of membrane permeability for individual substances: for glutamate in glutamate-producing strains of Brevibacterium lactofermentum and Corynebacterium glutamicum (Demain \& Birnbaum, 1968; Furuya et al., 1969), and for 5'-inosinic acid in Brevibacterium ammoniagenes (Furuya et al., 1969; Teshiba \& Furuya, 1983). The permeability towards these substances depends on the presence of biotin and manganese ions, respectively.

The second mechanism is associated with the functioning of special transport proteins. A transport protein is supposed to be responsible for both the entry and exit of the substrate. If the affinity of such a carrier protein for the external substrate is reduced by mutation, the uptake of the substrate will stop but the efflux will continue, resulting in accumulation of the metabolite in the medium. This mechanism is thought to be responsible for the excretion of lysine by $S-2-$ aminoethyl-L-cysteine (AEC)-resistant mutants of Escherichia coli (Halsall, 1975).

Finally, the third mechanism can, theoretically, be attributed to the functioning of specialized excretion systems. Thus, energy-dependent excretion of cAMP (Goldenbaum \& Hall, 1979), calcium ions (Rosen \& McClees, 1974), arsenate and some antibiotics (Foster, 1983) have been described in E. coli. A specific riboflavin excretase has been found in the yeast Pichia guiliermondii (Sibirny et al., 1978).

C. glutamicum has long been used as an industrial producer of L-lysine (Kinoshita et al., 1958;

\footnotetext{
Abbreviations: CCCP, carbonyl cyanide $m$-chlorophenylhydrazone; DCCD, $N, N^{\prime}$-dicyclohexylcarbodiimide; PCP, pentachlorophenol; TPP ${ }^{+}$, tetraphenylphosphonium; TPMP+, triphenylmethylphosphonium; AEC, $S$-2aminoethyl-L-cysteine; LHX, lysine hydroxamate; $\Delta \psi$, transmembrane electric potential.
} 
Ozaki \& Shiio, 1983). However, nothing has to our knowledge been published on transport and secretion of lysine by this micro-organism. An attempt is made in the present study to elucidate the mechanism(s) underlying lysine transport through the bacterial membrane.

\section{METHODS}

A wild-type C. glutamicum strain ATCC 13032 and mutants derived from it were used. Some details of the strains are given in Table 1. Spontaneous AEC-resistant mutants (S11 and S21) were selected from wild-type bacteria on minimal plates supplemented with glucose, $1 \mathrm{mg} \mathrm{AEC} \mathrm{ml}^{-1}$ and threonine. The rest of the mutants were selected after mutagenization with nitrosoguanidine. The mutants 34, 410 and 1-2-89, which are lysine producers, have an aspartokinase (the key enzyme of lysine biosynthesis) that is insensitive to feedback inhibition by a mixture of lysine and threonine (Kara-Murza et al., 1978; Leonova et al., 1981).

The cells were routinely grown at $30^{\circ} \mathrm{C}$ to the exponential phase (4-5 h) in Nutrient broth (Difco) containing $5 \%$ glucose with aeration provided by a shaker. Then they were collected on a filter (HAWP, Millipore, $0.45 \mu \mathrm{m}$ pore size, $48 \mathrm{~mm}$ diameter), washed with $\mathrm{Tris} / \mathrm{HCl}(0.01 \mathrm{M}, \mathrm{pH} \mathrm{7.3)}$ and suspended in the same buffer. The optical density of the suspension (0.4-0.6) was measured with a KFO photocolorimeter ( $530 \mathrm{~nm}$ maximum transmittance filter) in $5 \mathrm{~mm}$ lightpath cuvettes.

The rate of lysine transport was measured after adding radioactive lysine $\left[330 \mathrm{mCi} \mathrm{mmol}^{-1}\left(12 \cdot 2 \mathrm{GBq} \mathrm{mmol}^{-1}\right)\right.$ Amersham] to a bacterial suspension held at $30^{\circ} \mathrm{C}$. An automatic pipette was used to take $0.2-0.4 \mathrm{ml}$ samples at certain time intervals; the cells were collected on fibreglass filters (Whatman GF/F) mounted on a Millipore multifilter holder and washed with $10 \mathrm{ml} \mathrm{Tris} / \mathrm{HCl}$ buffer. The filters were dried, placed in scintillation vials and their radioactivity was counted with a Delta 300 scintillation counter. Since $\left[{ }^{14} \mathrm{C}\right] l y s i n e$ accumulation in cells was a linear function of incubation time up to $2 \mathrm{~min}$ (see Fig. 1), the value at the intersection of this line with the ordinate was taken as the amount of label adsorbed non-specifically by the filter. The appropriate correction was made in calculating the amount of lysine uptake.

To measure the intracellular lysine pool, the cells from 0.51 exponential culture were collected by centrifugation and washed twice with Tris/ $\mathrm{HCl}, \mathrm{pH} 7 \cdot 3$. The pellet was kept in an ice bath with $1 \mathrm{ml} 10 \%$ TCA for $30 \mathrm{~min}$. The cells were then sedimented by centrifugation, and TCA was removed with ether. The lysine content of the extract was determined with a Durrum D500 amino acid analyser. According to Clement et al. (1984) the intracellular water volume is considered to be $1.76 \mu \mathrm{l}(\mathrm{mg} \text { dry } w \mathrm{t})^{-1}$.

The membrane potential $(\Delta \psi)$ was determined by using the lipid-soluble cation triphenylmethylphosphonium $\left(\mathrm{TPMP}^{+}\right)$. The intracellular accumulation of $\left[{ }^{14} \mathrm{C}\right] \mathrm{TPMP}^{+}\left[100 \mu \mathrm{Ci} \mathrm{ml}^{-1}\left(3.7 \mathrm{MBq} \mathrm{ml}{ }^{-1}\right)\right]$ was studied by the same method as the transport of $\left[{ }^{14} \mathrm{C}\right]$ lysine. $\left[{ }^{14} \mathrm{C}\right] \mathrm{TPMP}{ }^{+}$accumulation attained equilibrium $15 \mathrm{~min}$ after adding the cation to the cells. The value of $\Delta \psi$ was calculated from the Nernst equation using the equilibrium intracellular concentration of $\mathrm{TPMP}^{+}$, its outside concentration being $5.5 \mu \mathrm{M}$. The non-specific binding of $\left[{ }^{14} \mathrm{C}\right] \mathrm{TPMP}^{+}$was determined by using cells treated with $1 \%$ toluene. The average value of $\Delta \psi$ was $180 \mathrm{mV}$. Ethanol $(0.5 \%)$ was used to dissolve some inhibitors. It did not affect the accumulation of $\left[{ }^{14} \mathrm{C}\right] l y s i n e$ or $\left[{ }^{14} \mathrm{C}\right] \mathrm{TPMP}{ }^{+}$.

To study the efflux of lysine, a bacterial suspension was incubated in Tris/ $\mathrm{HCl}(0.01 \mathrm{M}, \mathrm{pH} 7.3)$ in the presence of $\left[{ }^{14} \mathrm{C}\right] l y s i n e(1 \mu \mathrm{M})$ for $40 \mathrm{~min}$; the suspension was then quickly diluted 100 -fold with the same buffer prewarmed to $30^{\circ} \mathrm{C}$. Samples $(5 \mathrm{ml})$ were passed through fibreglass filters to collect and wash the cells.

Cells with no lysine pool were prepared by incubation with gramicidin $\mathrm{S}\left(10^{-5} \mathrm{M}\right)$ for $10 \mathrm{~min}$. The cells were collected on filters (HAWP, Millipore, $0.45 \mu \mathrm{m}$ pore size) and washed with Tris/ $\mathrm{HCl}(0.01 \mathrm{M}, \mathrm{pH} 7.3)$.

Cell proteins were labelled by the following procedure. Cells were grown in a glucose/salt medium for $24 \mathrm{~h}$ in the presence of $10 \mu \mathrm{M}-\left[{ }^{14} \mathrm{C}\right]$ lysine. Then they were collected by centrifugation and washed with $\mathrm{Tris} / \mathrm{HCl}(0.01 \mathrm{M}$, $\mathrm{pH} 7 \cdot 3$ ). Proteins were extracted by treating the cells with $5 \% \mathrm{TCA}$ at $90{ }^{\circ} \mathrm{C}$ for $10 \mathrm{~min}$. The TCA-insoluble pellets were collected on fibreglass filters and washed first with $5 \%$ TCA containing unlabelled lysine $\left(10^{-2} \mathrm{M}\right)$ and then with ethanol. Radioactivity of probes was measured.

Compounds used in the study were obtained from the following sources: carbonyl cyanide $m$-chlorophenylhydrazone (CCCP), valinomycin, sodium azide, Triton X-100 and $N$-ethylmaleimide were from Serva; $N, N^{\prime}$ dicyclohexylcarbodiimide (DCCD) and nigericin were from Calbiochem; pentachlorophenol (PCP) and rotenone were from BDH; monencin was from Lilly, and lysine analogues and nigericin were from Sigma. Gramicidin S was kindly provided by Professor G. F. Gauze (Institute for Search of New Antibiotics, Moscow).

\section{RESULTS}

\section{Lysine transport into the bacteria}

In studying the transport of a substance, one usually tries to prevent its subsequent metabolism after it has entered the cytoplasm. This is done by using a non-metabolizable 


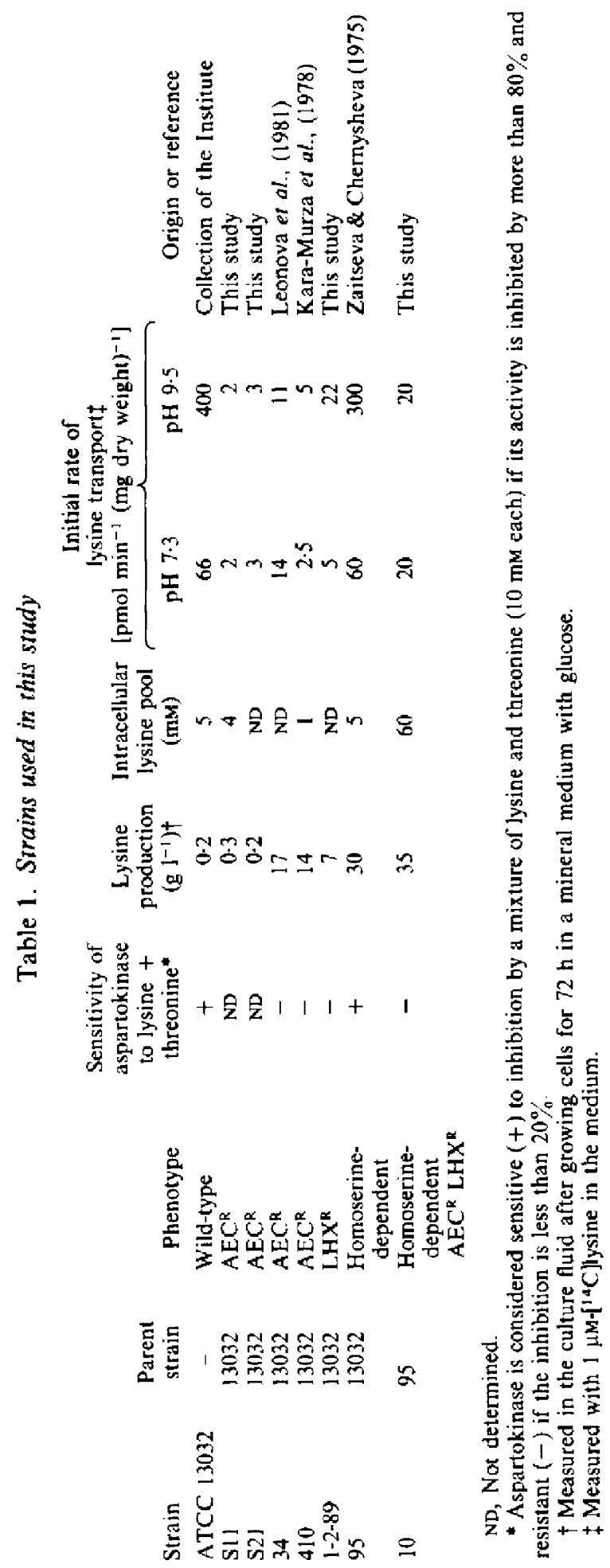




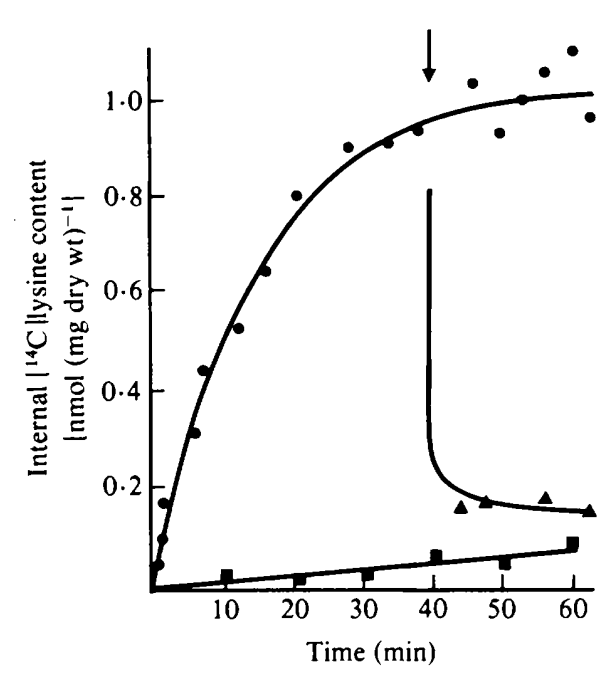

Fig. 1

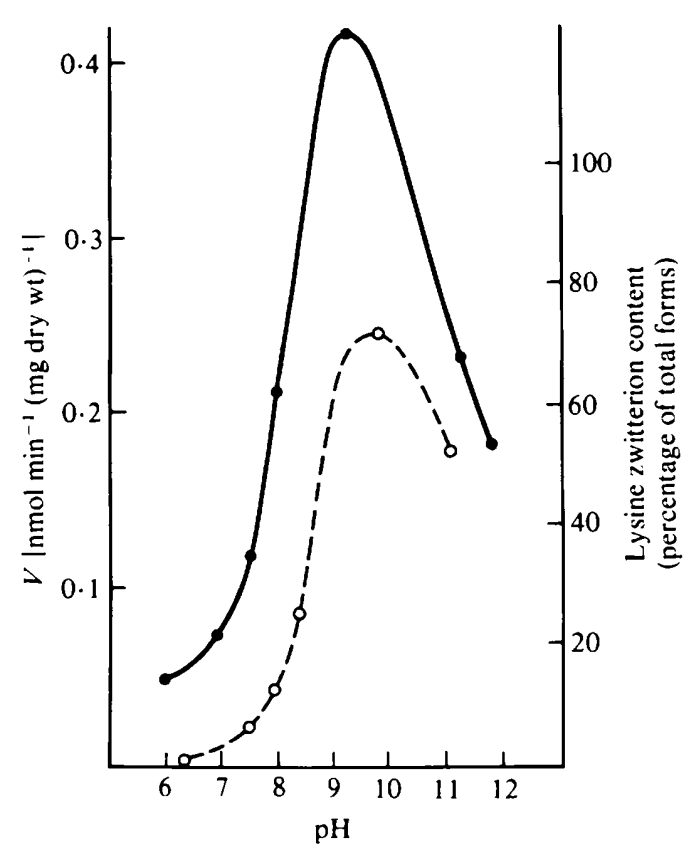

Fig. 2

Fig. 1. Incorporation of $\left[{ }^{14} \mathrm{C}\right]$ lysine into $C$. glutamicum 13032 cells $(\odot)$, into a TCA-insoluble fraction (D) and into cells treated with gramicidin $S$ (time of addition shown by arrow) $(\boldsymbol{A})$. $\left[{ }^{14} \mathrm{C}\right]$ Lysine concentration in the medium was $0.5 \mu \mathrm{M}$.

Fig. 2. Initial rate of $\left[{ }^{14} \mathrm{C}\right]$ lysine transport $(O)$ into C. glutamicum 13032 cells, and their content of lysine zwitterion as calculated from the Henderson-Hasselbalch equation (O), as functions of $\mathrm{pH}$. $\left[{ }^{14} \mathrm{C}\right]$ Lysine concentration in the medium was $0.5 \mu \mathrm{M}$.

derivative of the substance or by introducing a mutation into the genes responsible for utilization. We, however, did not face such a problem. We found that $\left[{ }^{14} \mathrm{C}\right] l y s i n e$ which entered C. glutamicum ATCC 13032 cells incubated in Tris/ $\mathrm{HCl}$ was not subject to any subsequent degradation: $95 \%$ of the label extracted with TCA from $C$. glutamicum cells after $30 \mathrm{~min}$ incubation was found in the lysine spot after paper chromatography. At the same time label incorporation into acid-insoluble material was quite low under our conditions (Fig. 1), and the cells lost almost all their accumulated lysine when exposed to gramicidin S (Fig. 1). This implied that the substance was stored in an osmotically active state in the cell cytoplasm. The treatment of bacteria with cold TCA (see Methods) also indicated that the lysine pool was between 4 and $5 \mathrm{mM}$ (Table 1). Nevertheless, the cells were able to accumulate $\left[{ }^{14} \mathrm{C}\right]$ lysine against a pre-existing gradient (Fig. 1).

The initial rate of uptake of label increased in proportion to the outside concentration which was varied from $0 \cdot 1-5 \mu \mathrm{M}$. At higher concentrations the linear portion of the accumulation $v s$ time curve extended over less than $5 \mathrm{~s}$; therefore we were unable to determine the initial rate accurately. For this reason saturation on the Michaelis curve was not attained. For the same reason we could not determine the exact values of $K_{\mathrm{m}}$ and $V_{\max }$. From approximate calculations the value of $K_{\mathrm{m}}$ lay somewhere between 1 and $5 \mu \mathrm{M}$ and $V_{\max }$ was about $0.8 \mathrm{nmol} \mathrm{min}{ }^{-1}(\mathrm{mg}$ dry $w t)^{-1}$.

As follows from Table 2, the system responsible for lysine entry was rather specific. It recognized only close structural derivatives of the amino acid. The presence of both amino groups seemed to be required for recognition. A modification of either of them ( $N \alpha$-acetyllysine, $N \varepsilon$-formyllysine) made the compound unable to compete with lysine for entry, while 
Table 2. Transport of $\left[{ }^{14} \mathrm{C}\right]$ lysine by C. glutamicum ATCC 13032 in the presence of structural analogues

$\left[{ }^{14} \mathrm{C}\right] \mathrm{L} y \operatorname{sine}(1 \mu \mathrm{M})$ was present in all the experiments. $\delta$-Hydroxylysine was a mixture of $\mathrm{DL}$ - and $\mathrm{DL}$-alloforms; except for D-lysine the other compounds were $\mathrm{L}$-forms. The initial rate of $\left[{ }^{14} \mathrm{C}\right]$ lysine entry (equivalent to $100 \%$ ) was $0.06 \mathrm{nmol} \mathrm{min}^{-1}$ (mg dry wt) ${ }^{-1}$.

$\begin{array}{lc}\text { Analogue }(40 \mu \mathrm{M}) & \begin{array}{c}\text { Initial rate of entry } \\ (\%)\end{array} \\ \text { None } & 100 \\ \text { L-Lysine } & 3 \cdot 5 \\ \text { S-2-Aminoethyl-L-cysteine } & 15 \\ \text { Lysine hydroxamate } & 56 \\ \text { Spermine } & 56 \\ \text { Arginine } & 56 \\ \text { Ornithine } & 67 \\ \text { Lysine methyl ester } & 76 \\ \text { No-Acetyllysine } & 80 \\ \text { Ne-Formyllysine } & 98 \\ \delta \text {-Hydroxylysine } & 98 \\ \text { Diaminopimelinic acid } & 100 \\ \text { D-Lysine } & 100\end{array}$

Table 3. Effect of various substances on lysine transport and TPMP+ accumulation by C. glutamicum ATCC 13032

$\begin{array}{llrrr}\text { Substance } & \begin{array}{c}\text { Concn } \\ (\mathrm{mM})\end{array} & \begin{array}{c}\text { Lysine } \\ \text { entry } \\ \mathbf{( \% )}\end{array} & \begin{array}{c}\text { Lysine } \\ \text { retained } \\ (\%)\end{array} & \begin{array}{c}\text { TPMP }^{+} \\ \text {accumulation } \\ (\%)\end{array} \\ \text { None } & - & 100 & 100 & 100 \\ \text { KCN } & 1 & 150 & 97 & 44 \\ \text { Sodium azide } & 1 & 108 & 98 & \text { ND } \\ \text { Rotenone } & 0 \cdot 01 & 103 & 97 & \text { ND } \\ \text { DCCD } & 0 \cdot 1 & 120 & 100 & 338 \\ \text { CCCP } & 0 \cdot 01 & 15 & 100 & 11 \\ \text { PCP } & 0 \cdot 1 & 17 & 103 & 14 \\ \text { Nigericin } & 0 \cdot 005 & 34 & 98 & 86 \\ \text { Monencin } & 0 \cdot 04 & 38 & 85 & 80 \\ \text { Nigericin }+\mathrm{KCl} & 0 \cdot 005+0 \cdot 01 & 22 & \text { ND } & \text { ND } \\ \text { TPP } & 0 \cdot 1 & 49 & 99 & 18 \\ \text { Valinomycin }+\mathrm{KCl} & 0 \cdot 005+0 \cdot 01 & 25 & 100 & 32 \\ \text { KCl } & 1 & 81 & 99 & \text { ND } \\ \text { NaCl } & 1 & 89 & 94 & \text { ND }\end{array}$

ND, Not determined.

substitutions in the carboxyl moiety (lysine hydroxamate) only partially reduced the affinity of the carrier for the derivative.

Experiments on lysine transport as a function of $\mathrm{pH}$ (Fig. 2) indicated that both the initial rate of uptake and the equilibrium level of accumulation appreciably increased with increasing $\mathrm{pH}$ up to $9 \cdot 5-9 \cdot 7$, and then declined at higher $\mathrm{pH}$ values. There was no lysine accumulation whatsoever at $<\mathrm{pH} 5$. A similar result was obtained in a study of lysine transport in Rickettsia prowazekii (Zahorchak \& Winkler, 1983). Measurements of $\Delta \psi$ at different $\mathrm{pH}$ values and of the lysine potential $\left(\Delta \mu_{1 y s}\right)$ led these authors to the conclusion that the increase in lysine uptake correlated with an increase of $\Delta \psi$. We also measured $\Delta \psi$ as a function of $\mathrm{pH}$ and found that it increased from $180 \mathrm{mV}$ at $\mathrm{pH} 7 \cdot 3$ to $215 \mathrm{mV}$ at $\mathrm{pH} 9 \cdot 4$. Meanwhile, the initial rate of $\left[{ }^{14} \mathrm{C}\right]$ lysine uptake (Fig. 2) and the steady state level of accumulation (data not shown) increased three or fourfold. However, the data shown in Table 3 imply that a correlation between TPMP+ accumulation and lysine transport existed only for exposure to permeant cations $\left(\mathrm{TPP}^{+}\right)$, valinomycin and uncouplers (CCCP, PCP). However, treatment of cells with electroneutral 


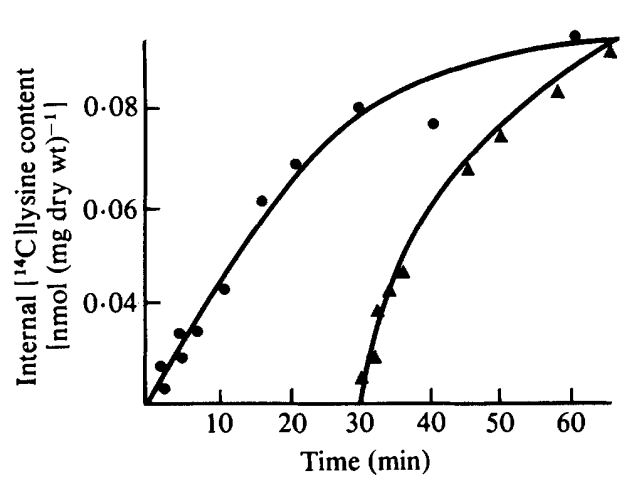

Fig. 3

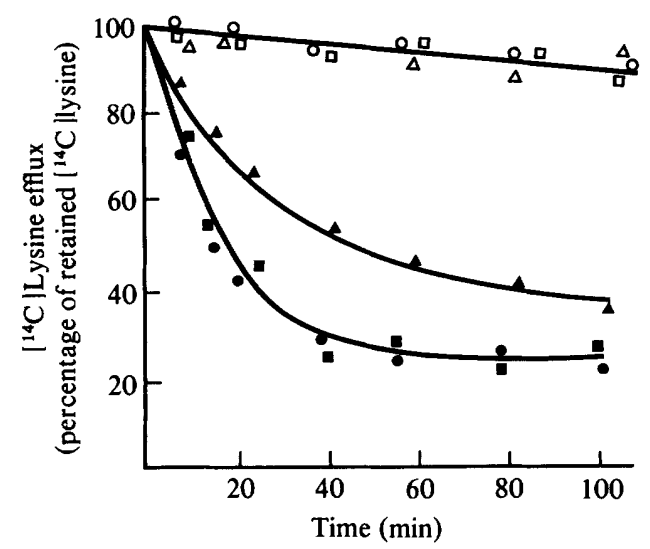

Fig. 4

Fig. 3. Exchange of intra- and extracellular lysine in C. glutamicum 13032. The suspension of cells was divided into two portions: to one portion $0.9 \mu \mathrm{M}$-unlabelled lysine $+0 \cdot 1 \mu \mathrm{M}-\left[{ }^{14} \mathrm{C}\right] \mathrm{lysine}$ were added (O); the other portion was preincubated for $30 \mathrm{~min}$ with $0.9 \mu \mathrm{M}$-unlabelled lysine and then $0.1 \mu \mathrm{M}$ $\left[{ }^{14} \mathrm{C}\right]$ lysine was added $(\mathbf{A})$.

Fig. 4. Effect of exogenous lysine (0.1 mM) on efflux of labelled lysine from C. glutamicum $13032(0)$, strain $95(\square)$ and strain $10(\boldsymbol{D}) . O, \square, \triangle$, Efflux of labelled lysine from the same strains in a medium without lysine.

ionophore antibiotics (nigericin, monensin) partially suppressed lysine transport while the TPMP $^{+}$accumulation level remained virtually unchanged. Moreover, the drop of $\Delta \psi$ caused by uncouplers did not cause the release of intracellular lysine, a fact that is at variance with the idea of a passive distribution of lysine according to the electric potential gradient. It may be worth noting that inhibitors of ATPase (DCCD, sodium azide) or of respiration (cyanide, rotenone) and $\mathrm{K}^{+}$or $\mathrm{Na}^{+}$ions did not affect lysine uptake and efflux.

An unexpected finding was the weak temperature dependency of lysine transport. The $Q_{10}$ value of the process was $1 \cdot 6$, which is close to the $Q_{10}$ of diffusion.

As mentioned above, the $\left[{ }^{14} \mathrm{C}\right]$ lysine uptake $v$ s incubation-time curve reached a plateau (Fig. 1). Since the cells already had a significant pool of unlabelled lysine when the label was added, the accumulation curve pattern observed could be thought to result from an interaction of two processes: entry of ${ }^{14} \mathrm{C}$-labelled molecules and exit of labelled and unlabelled molecules.

The following facts support this suggestion: (i) the initial rate of $\left[{ }^{14} \mathrm{C}\right]$ lysine uptake was the same in cells treated with gramicidin S (no lysine pool) and in untreated cells; (ii) Fig. 3 shows that bacteria at equilibrium were still capable of taking up the label. It followed that the steadystate level was a result of exchange between extra- and intracellular lysine, mediated by the carrier. This notion was also supported by the fact that exogenous lysine could replace intracellular lysine (Fig. 4). However, cells loaded with $\left[{ }^{14} \mathrm{C}\right]$ lysine and placed in a lysine-free medium showed almost no lysine efflux (Fig. 4); no lysine efflux occurred when cells were placed in buffers of $\mathrm{pH} 9.7$ or 5.5. Apparently, the switching on of lysine efflux requires a triggering of lysine entry. This idea was supported by the following observations: (i) lysine efflux was induced by adding lysine or its close structural derivatives to the cells but not by other amino acids; (ii) inhibition of lysine uptake at $\mathrm{pH} 5$ stopped the exchange; (iii) the rate of lysine efflux dropped in the presence of inhibitors of lysine transport, e.g. CCCP. Both the uptake and the exchange diffusion of lysine in C. glutamicum appeared to be mediated by one and the same system.

Table 1 shows the functioning of lysine transport in various mutants. All analogue-resistant mutants (both spontaneous, selected for AEC resistance and unable to produce lysine, and obtained after mutagenization and selected for maximum production) had an altered system of lysine transport: their initial rate of lysine uptake was reduced and the increase in uptake at 


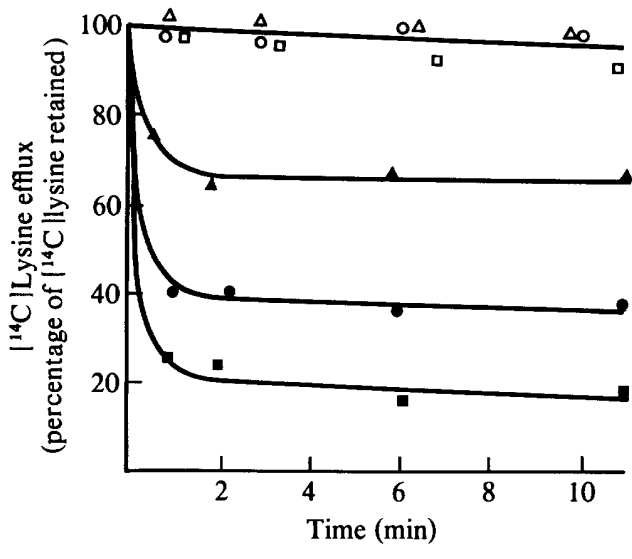

Fig. 5

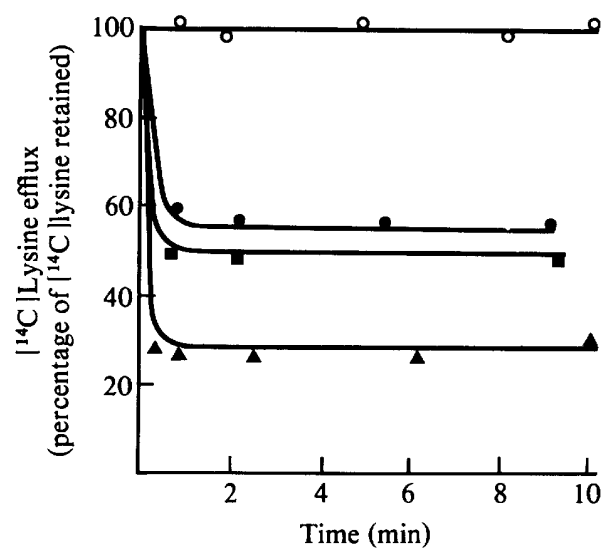

Fig. 6

Fig. 5. Effect of $\mathrm{NaCl}(2 \mathrm{M})$ on lysine efflux from C. glutamicum $13032(\mathrm{O})$, strain $10(\boldsymbol{A})$ and strain $\mathrm{S} 11$ ( $\square$ ). $O, \square, \triangle$, Efflux from untreated cells of the same strains.

Fig. 6. Effect of polymixin $M(O)$ at $25 \mu \mathrm{M}$, gramicidin $S(\Delta)$ at $10 \mu \mathrm{M}$ and Triton $X-100(\square)$ at $0.5 \%$ on lysine efflux from $C$. glutamicum 13032 . $O$, Efflux of labelled lysine from the same strain in a medium without additions.

pH 9.5 was absent (or suppressed). At the same time, a homoserine-dependent, AEC-sensitive lysine producer (strain 95) appeared to have normal transport activity. This suggested that the systems of lysine transport and excretion were not directly related to each other.

\section{Lysine excretion from the bacteria}

Obviously, the exchange mechanism that we found in wild-type bacteria could not account for the accumulation of lysine in the growth medium of producer strains. It might be suggested therefore that mutations changed the transport system of producer cells in such a way that they became able to excrete lysine in the absence of exogenous lysine. However, the data presented in Fig. 4 indicated that this was not the case. Lysine efflux from producer strain 95 (Table 1), which retained its transport activity, could only occur by the exchange of extra- and intracellular lysine, as is also the case for its wild-type parent. The question arose by what means other than the transport system could the producer cells excrete lysine. We supposed that our bacteria might possess channels that opened in response to accumulation of excess lysine in the cytoplasm. It was possible to simulate such a situation by suddenly increasing the osmotic pressure in the incubation medium. If a suspension of cells loaded with $\left[{ }^{14} \mathrm{C}\right] l y s i n e$ was placed in a $2 \mathrm{M}$ solution of $\mathrm{KCl}$ or $\mathrm{NaCl}$, the cells should lose water, thus increasing the concentration of various metabolites, including lysine. If the lysine excretion system was indeed triggered by a certain threshold concentration of amino acid, we would be able to detect its efflux from the cells. Addition of $2 \mathrm{M}-\mathrm{NaCl}$ to a suspension of cells was followed by a rapid efflux of lysine which ended in less than a minute (Fig. 5). Accumulation of lysine was completely suppressed under these conditions. However, if a lower concentration $(0.5 \mathrm{M})$ of salt was used, a small efflux was obtained after exposure of the cells first to the salt and then to exogenous lysine (Table 4). This suggested independent functioning of the lysine carrier and the lysine channels. The following facts might give support to this idea: (i) the sensitivity of the excretion system to $\mathrm{NaCl}$ increased with culture age while the transport system activity decreased; (ii) the $\mathrm{NaCl}$-induced efflux was insensitive to CCCP.

$\mathrm{NaCl}$ did not cause extensive changes in membrane permeability. This was shown by the 
Table 4. Effect of salts and lysine on excretion of $\left[{ }^{14} \mathrm{C}\right]$ lysine from C. glutamicum ATCC 13032

\begin{tabular}{lc} 
Additions & $\begin{array}{c}\text { Percentage } \\
\text { lysine excretion* }\end{array}$ \\
$\mathrm{None}$ & 0 \\
$\mathrm{NaCl}(0.5 \mathrm{M})$ & 20 \\
$\mathrm{NaCl}(0.5 \mathrm{M})+$ lysine $(0.1 \mathrm{mM})$ & 33 \\
$\mathrm{KCl}(0.5 \mathrm{M})$ & 15 \\
$\mathrm{KCl}(0.5 \mathrm{M})+$ lysine $(0.1 \mathrm{~mm})$ & 49.5 \\
\multicolumn{2}{c}{ Ratio of excreted lysine to retained lysine. }
\end{tabular}

following experiment. Cell proteins were labelled with $\left[{ }^{14} \mathrm{C}\right] l y s i n e:$ the amount of label in cell proteins was the same before and after treatment of cells with $2 \mathrm{M}-\mathrm{NaCl}$.

Since the cellular permeability for glutamate in C. glutamicum and for 5 -inosinic acid in $B$. ammoniagenes can be increased by treatment with detergents, fatty acids or penicillin (Demain \& Birnbaum, 1968; Furuya et al., 1969; Teshiba \& Furuya, 1983), we did direct experiments to check whether membrane-active agents could affect $\left[{ }^{14} \mathrm{C}\right]$ lysine exit from $C$. glutamicum cells. The experiments indicated that detergents (gramicidin $S$, Triton $\mathrm{X}-100$ ) and polymixin $\mathrm{M}$, which interacts with membrane lipids, did induce the opening of hypothetical lysine channels (Fig. 6). Mutants were as sensitive to the above agents as wild-type cells. Lysis of cells was not observed after the detergent treatment.

\section{DISCUSSION}

\section{Lysine uptake by C. glutamicum}

The transport of various substances in bacteria is accomplished by means of carrier proteins which are specific for individual compounds and their structural analogues (Boos, 1974). In the majority of cases this is an active, energy-requiring process which results in a marked gradient of substrate concentration between the cytoplasm and environment. Some of the bacterial transport systems utilize the energy of the proton transmembrane electrochemical potential $\left(\Delta \bar{\mu}_{\mathrm{H}^{+}}\right)$which has two components, electrical $(\Delta \psi)$ and osmotic $(\Delta \mathrm{pH})$.

Hamilton (1975) proposed the chemiosmotic model of transport based on the ideas of Mitchell. In particular, the model implied that cations, e.g. basic amino acids, are transported by a uniport, an electrogenic process which occurs in response to a $\Delta \psi$, which is negative inside the cell. Subsequent studies confirmed this model for a number of substances. Lysine, for instance, which is positively charged at a physiological $\mathrm{pH}$, is indeed distributed according to $\Delta \psi$ in Staphylococcus aureus and R. prowazekii (Niven \& Hamilton, 1973, 1974; Zahorchack \& Winkler, 1983).

However, Kaback and co-workers (Ramos \& Kaback, 1977; Robertson et al., 1980) showed that both $\Delta \psi$ and $\Delta \mathrm{pH}$ influence the steady-state level of lysine accumulation and the kinetics of lysine transport in membrane vesicles of $E$. coli. These authors consider that "carrier molecules must play a dynamic role in modulating the response of given transport substrate to the electrochemical proton gradient'. Also, the existence of lysine producer cells does not fully correspond to Hamilton's model: it is unclear how bacteria could export from their cytoplasm a positively charged substance against the electric potential gradient. Lysine exit may occur by cation/lysine antiport, but we failed to stimulate efflux of intracellular lysine by addition of $\mathrm{Na}^{+}$ or $\mathrm{K}^{+}$(Table 3 ).

The present study indicates that $C$. glutamicum possesses a highly specific system of active lysine transport, the most important features of which are as follows. (i) The system acts asymmetrically, i.e. the substrate moves into the cell but not outwards, in spite of a high concentration inside. However, if lysine is present on both sides of the membrane, exchange diffusion may occur (Figs 3 and 4). The carrier, apparently, has no affinity for the inner substrate until it 
binds substrate on the outside. (ii) The maximum rate of transfer and the intracellular accumulation level are observed at a $\mathrm{pH}$ close to the isoelectric point for lysine ( $\mathrm{pH}$ 9.74).

Let us consider the latter fact. Lysine may exist in four forms with charges of $+2,+1,0$ and -1 . The $\mathrm{p} K$ values for the $\alpha$-carboxyl, $\alpha$-amino and $\varepsilon$-amino groups $(2 \cdot 18,8.95$ and $10 \cdot 53$, respectively) may be used to calculate the content of uncharged lysine as a function of $\mathrm{pH}$. The results of such calculations by means of the Henderson-Hasselbalch equation $\left(\mathrm{pH}=\mathrm{p} K_{\mathrm{a}^{+}}+\right.$ $\log$ base/acid) are given in Fig. 2. The peak of transport activity corresponds to the maximum content of lysine in the form of a zwitterion. If the active site of the carrier seems to have the greatest affinity for lysine zwitterion rather than cation we suggest an alternative to Hamilton's hypothesis, i.e. that lysine translocation is accomplished in symport with $\mathrm{H}^{+}$by means of both components $-\Delta \psi$ and $\Delta \mathrm{pH}$ - of the electrochemical potential $\Delta \bar{\mu}_{\mathrm{H}^{+}}$. If this is the case, it becomes clear why lysine accumulation is not always correlated with $\Delta \psi$.

At present, however, we cannot discriminate between the two possible mechanisms of lysine transport. We cannot discount the possibility, for example, that lysine is retained in the cytoplasm by means of a Donnan potential and that due to this lysine efflux does not occur in the presence of uncouplers.

All the AEC-resistant mutants had lowered lysine transport rates (Table 1). The acquisition of AEC resistance seems to be accompanied by a drop in the carrier activity. A transport mutation alone does not lead to changes in the intra- or extracellular lysine levels (e.g. mutants S11 and S21). Hence the ability to hyperproduce lysine is due primarily to disturbances in regulation of its biosynthesis. A combination of the latter type of mutation with a transport mutation may somewhat increase the lysine production level owing to the absence of re-accumulation of excreted lysine.

\section{Excretion of lysine by C. glutamicum}

Our most unexpected result was that resting producer cells, like the wild-type bacteria, did not transport their intracellular lysine outwards; their transport system could maintain only an equivalent exchange of intra- and extracellular lysine. We thought that the bacteria might excrete lysine through channels whose opening is triggered by the lysine concentration surpassing a certain threshold level, as the producer cells had unbalanced synthesis of the amino acid. Having released excess lysine, the channel would close to retain the amount of amino acid necessary for the cell's metabolism. The possible existence of such channels was demonstrated in experiments in which the osmotic pressure of the medium was rapidly increased (Fig. 5). The observed efflux of lysine was due to a rapid rise in intracellular lysine concentration since osmotic stress is known to be followed by loss of water from the cells (Griffin, 1981). The channel properties seem to depend on the cytoplasmic membrane structure, and subsequent experiments demonstrated opening of the hypothetical channels after exposure to membrane-active agents (Fig. 6). The channel permeability may also depend on the fatty acid composition of the membrane. The result obtained by Hänel et al. (1981) may be interpreted in terms of our hypothesis. They found the following effects of oxygen limitation on a $C$. glutamicum lysine producer: (i) the ratio of saturated to unsaturated fatty acids in the membrane was altered; (ii) the extracellular lysine concentration decreased while the intracellular concentration increased.

The lysine channels seem to play the role of safety valves in wild-type cells; they open in response to emergency situations that result in the lysine level rising. There are examples of situations when the increase of intracellular metabolite concentration leads to the efflux of this substance into the medium. Thus suppression of $\gamma$-glutamyl transpeptidase in Proteus mirabilis and some other bacteria resulted in an increased intracellular glutathione content and an efflux of this metabolite (Nakayama et al., 1984). In E. coli, inhibition of RNA synthesis was accompanied by a 100-fold increase in glutamate secretion (Broda, 1968). According to the author, the increase of membrane permeability under these conditions was due to accumulation of metabolites that could not be utilized in biosynthesis.

The nature, mechanism of action or specificity of the hypothetical channels of $C$. glutamicum are far from being understood at present. They should be the subject of further investigation. 


\section{REFERENCES}

Boos, W. (1974). Bacterial transport. Annual Review of Biochemistry 43, 123-146.

BrodA, P. (1968). Ribonucleic acid synthesis and glutamate excretion in Escherichia coli. Journal of Bacteriology 96, 1528-1534.

Clement, Y., Escoffier, B. Trombe, M. C. \& LANEELE, J. (1984). Is glutamate excreted by its uptake system in Corynebacterium glutamicum? A working hypothesis. Journal of General Microbiology 130, 2589-2594.

Demain, A. L. \& Birnbaum, J. (1968). Alteration of permeability for the release of metabolites from the microbial cell. Current Topics in Microbiology 46, 126.

Foster, T. J. (1983). Plasmid-determined resistance to antimicrobial drug and toxic metal ions in bacteria. Microbiological Reviews 47, 361-409.

Furuya, A., Misawa, M., Nara, T., Abe, S. \& KinOSHITA, S. (1969). Metabolic controls of accumulation of aminoacids and nucleotides. In Fermentation Advances, pp. 177-198. Edited by D. Perlman. New York \& London: Academic Press.

Goldenbaum, P. E. \& Hall, G. A. (1979). Transport of cyclic adenosine- $3^{\prime}, 5^{\prime}$-monophosphate across Escherichia coli vesicle membranes. Journal of Bacteriology 140, 459-467.

Griffin, D. M. (1981). Water and microbial stress. Advances in Microbial Ecology 5, 137-210.

Halsall, D. M. (1975). Overproduction of lysine by mutant strains of Escherichia coli with defective lysine transport system. Biochemical Genetics 13, 109-124.

Hamilton, W. A. (1975). Energy coupling in microbial transport. Advances in Microbial Physiology 12, 1-53.

HäNEL, F., Hillinger, M. \& GRÄFE, U. (1981). Effect of oxygen limitation on cellular L-lysine pool and lipid spectrum in Corynebacterium glutamicum. Biotechnology Letters 3, 461-464.

Kara-Murza, S. N., IVanovsKaya, L. V. \& ZhDANOVA, N. I. (1978). Effect of amino acids on $\beta$ aspartokinase activity of a wild type Corynbacterium glutamicum strain and its mutant. Prikladnaya biokhimia i mikrobiologia 14, 345-349 (in Russian).

Kinoshita, S., Nakayama, K. \& Kitaga, S. (1958). L-Lysine production using microbial auxotroph. Journal of General and Applied Microbiology 4, 128-129.

Leonova, T. V., IVANovskaya, L. V., ZhDanova, N. I. \& Kara-Murza, S. N. (1981). Some properties of analogue-resistant mutants of $C$. glutamicum pro- ducing L-lysine. In Abstract Book of the FEMS Symposium on Overproduction of Microbial Products, pp. 212-213. Czechoslovakia: Hradec Kralove.

Nakayama, K., Kumagai, H. \& Tochikura, T. (1984). Leakage of glutathione from bacterial cells caused by inhibition of $\gamma$-glutamyltranspeptidase. Applied and Environmental Microbiology 47, 653657.

Niven, D. F. \& Hamilton, W. A. (1973). Valinomycin-induced amino acid uptake by Staphylococcus aureus. FEBS Letters 37, 244-248.

Niven, D. F. \& HaMiLton, W. A. (1974). Mechanisms of energy coupling to the transport of amino acids by Staphylococcus aureus. European Journal of Biochemistry 44, 517-522.

Ozakı, H. \& ShIIO, J. (1983). Production of lysine by pyruvate kinase mutants of Brevibacterium flavum. Agricultural and Biological Chemistry 47, 1569-1576.

RAMOS, S. \& KABACK, H. R. (1977). The relationship between the electrochemical proton gradient and active transport in Escherichia coli membrane vesicles. Biochemistry 16, 854-859.

Robertson, D. E., Kaczorowski, H. J., Garcia, M.-L. \& KABACK, H. R. (1980). Active transport in membrane vesicles from Escherichia coli: the electrochemical proton gradient alters the distribution of the lac carrier between two different kinetic states. Biochemistry 19, 5692 5702.

Rosen, B. P. \& MCCleEs, J. S. (1974). Active transport of calcium in inverted membrane vesicles of Escherichia coli. Proceedings of the National Academy of Sciences of the United States of America 71, 50425046.

Sibirny, A. A., Shavlovsky, G. M., Ksheninskaya, G. P. \& OrlovsKY, A. G. (1978). Effect of glucose and its derivatives on the systems of absorption and excretion of riboflavin in yeast Pichia guilliermondii. Biokhimiya 43, 1414-1422 (in Russian).

Teshiba, S. \& FURUyA, A. (1983). Mechanisms of 5'. inosinic acid accumulation by permability mutants of Brevihacterium ammoniagenes. III. Intracellular 5'IMP pool and excretion mechanisms of 5'-IMP. Agricultural and Biological Chemistry 47, 2357-2363.

ZAHORCHAK, R. J. \& WINKLER, H. H. (1983). Transmembrane electrical potential in Rickettsia prowaze$k i i$ and its relationship to lysine transport. Journal of Bacteriology 153, 665-671.

Zaitseva, Z. M. \& Chernysheva, I. P. (1975). Some properties of $\beta$-aspartokinase from Micrococcus glutamicus-95. Biokhimiya 40,71-75 (in Russian). 